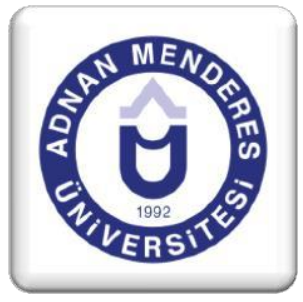

\title{
Sahte ve Muhteviyatı İtibariyle Yanıltıcı Belge Düzenleme ve Kullanma Suçunda Manevi Unsur
}

\author{
Demet AKDENIZ ${ }^{1}$
}

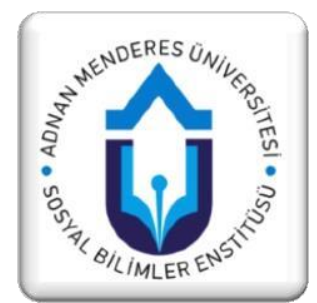

\section{ÖZET}

Kamu hizmetlerinin temel finansman kaynağı olan vergiler, devlet için hayati öneme sahiptir. Ancak aynı zamanda vergiler, hem maddi açıdan hem de yerine getirilmesi ödevler bakımından mükelleflerin üzerinde ciddi bir yük oluşturmaktadır. Mükellefler, bu yükten kurtulmak için çeşitli hile ve yöntemlere başvurmaktadırlar. Bu gibi fiillerin önlenmesi amacıyla bazı eylemler suç olarak tanımlanıp yaptırıma bağlanmıştır. Vergi kaçakçılığı suçlarını oluşturan fiiller de Vergi Usul Kanunu'nun 359. maddesinde düzenlenmiş ve karşılığında hürriyeti bağlayıcı cezalar öngörülmüştür. Bu çalışmada, vergi kaçakçılığı suçunu oluşturan sahte ve muhteviyatı itibariyle yanıltıcı belge düzenleme ve kullanma fiilleri suçun unsurlarından olan manevi unsur açısından incelenecektir. Ayrıca, uygulama ve öğreti için önemli olan ve kaynak teşkil eden yargı kararlarından yararlanılacaktır.

Anahtar Kelimeler: Vergi Kaçakçılı̆̆ı, Suçun Unsurları, Manevi Unsur

\section{Moral Element in the Crime of Issuing and Using False Document and Misleading Document}

\begin{abstract}
Taxes which are the main sources of public services funding, have crucial importance for state. At the same time, taxes lay a serious burden on taxpayers in terms of both obligations owed and financially.Taxpayers go to various tricks and methods to get rid of this burden. In order to prevent such public nuisance, several acts have been defined as crime and sanctions have been imposed. Actions which consitute the crimes of tax evasion have been also regulated under Article 359 of Tax Procedure Law and punishment restriction freedom has been envisaged. In this study, the acts of issuing and using false document and misleading document constituting the crime of tax evasion will be examined in terms of moral element of the elements of the crime. And also, judicial decisions will be utilized which are important for practice and doctrine.
\end{abstract}

Keywords: Tax Evasion, Elements of Crime, Moral element

\footnotetext{
1 Arş. Gör., Adnan Menderes Üniversitesi, Nazilli İIBF, Maliye Bölümü Mali Hukuk ABD, demet.akdeniz@adu.edu.tr
} 


\section{Giriş}

Kamu kesiminin en büyük gelir kaynağı olan vergilerin zamanında ve eksiksiz ödenmesi devletin yerine getirmesi gereken kamu hizmetleri bakımından oldukça önemlidir. Ancak vergilemenin yükümlü psikolojisi üzerindeki olumsuz etkileri aşikardır. Bu psikolojideki mükellef vergi kaçırma yollarına başvurabilmekte veya yerine getirmesi gereken yükümlülüklerden kaçınabilmektedirler. Bunları önlemek için vergi hukukunun bir alt dalı olan vergi ceza hukukunda vergi alacağının zamanında ve tam olarak alınabilmesi için bazı fiiller kabahat bazıları suç olarak düzenlenmiştir. Kabahatlerin yaptırımı idare tarafından idari cezalarla verilirken, vergi suçları adli yargının görev alanına girmekte ve karşılığında hürriyeti bağlayıcı ceza öngörülmektedir.

Vergi Usul Kanunu (VUK) ${ }^{2}$ 'nun 359. maddesinde düzenlenen vergi kaçakçıllı̆̆ suçu da tüm suçlarda olduğu gibi suç genel teorisindeki suçun unsurları bakımından incelenebilir. Çalışmamızın da konusunu oluşturan manevi unsur bakımından bu suç kasten işlenebilen suçlardandır. 4369 sayılı kanunla yapılan değişiklikle kanun metninden muhteviyatı itibariyle yanıltıcı belge ve sahte belge kullanma fiilleri için aranan "bilerek" ifadesi kaldırılmıştır. $\mathrm{Bu}$ değişiklik, kullanma fiili açısından kastın aranmayacağı tartışmalarına sebebiyet vermiştir. Ancak bu ifadenin kaldırılması suçta kastın aranmayacağ gelmemelidir. Manevi unsur failin iç dünyasıyla ilgili olduğu için, kastın tespiti ve kanıtları da kolay olmamaktadır. Buna ilişkin yargı kararları da önem arz etmektedir.

Çalışmada öncelikle vergi suçları ve özel olarak da vergi kaçakçılığı suçundan genel olarak bahsedildikten sonra bu suç manevi unsurları bakımından ele alınacaktır. Çalışmada yapılan değerlendirmeler içtihatlarla da desteklenerek açıklanmaya çalışılmıştır. Nitekim yüksek mahkeme kararları kanunların uygulanmasında yol gösterici nitelikte olduğu için en az teori kadar önemlidir.

\section{Genel Olarak Vergi Suçları}

Devletin kamu hizmetlerini karşılanmasında en önemli finansman kaynağı olan vergilerin zamanında ve eksiksiz toplanabilmesi için mükellef ve sorumlulara bir takım ödevler ve yükümlülükler yüklenmesi gerekmektedir. Öyle ki, zora dayalı olarak alınan bu vergilere ilişkin kurallara uymayanlara ise yaptırım öngörülmelidir. Aksi halde ödev ve yükümlülük içeren kuralların bir anlamı kalmaz.

Vergi suçları, en yalın tanımlamayla, vergi kanunlarınca öngörülen görev ve yükümlülüklere aykırı hareket edilmesi sonucu karşılığında yaptırım öngörülmüş hukuka aykırı eylemlerdir. Vergi suçlarıyla korunan hukuki değer kamu yararıdır. Çünkü vergi yasalarının gerekleri zamanında ve eksiksiz yerine getirildiğinde hazinenin vergi kaybı önlenmekte ve kamu hizmetlerinin finansmanı için gerekli kaynaklar toplanarak nihayetinde kamu yararına ulaşılmış olacaktır (Edizdoğan, Taş ve Çelikkaya, 2007: 7).

\footnotetext{
${ }^{2}$ Resmi Gazete Tarih: 10.01.1961, Sayı: 10703-10705 (Çalışmamızda bundan sonra bu kanun "VUK” olarak ifade edilecektir.)
} 
Anayasa'da, vergi ödevinin özel olarak düzenlenmiş olmasına rağmen vergi suç ve cezalarına ilişkin özel bir düzenleme yer almamaktadır. Suç ve cezalara ilişkin esasların belirtildiği Anayasa'nın 38. maddesi hükmü ile Türk Ceza Kanunu (TCK) $)^{3}$ 'nun genel hükümleri vergi suçları için de geçerlidir (Uğur ve Elibol, 2015: 84).

Tüm suçlarda olduğu gibi vergi suç ve kabahatlerinin de ortak özelliği ortada kanuna aykırı bir davranışın bulunması ve aynı zamanda yaptırım gerektirmesidir (Karakoç, 2016: 105). Her ne kadar yaptırıma bağlanan tüm fiiller suç olarak adlandırılsa da aslında bunlar suç ve kabahat olarak ayrılmaktadır. Vergi kabahatleri, idari yaptırım öngörülen ve vergi idaresi tarafindan cezalandırılan eylemlerdir. VUK'da düzenlenen vergi ziyaı ve usulsüzlük fiilleri esasen vergi kabahatidir. Vergi kabahatlerinin tespiti ve cezaların kesilmesi yargısal değil idari işlemle olmaktadır. Yani idare hem taraf hem yargıç görevi üstlenmektedir (Öncel, Kumrulu ve Çağan, 2013: 210). Vergi suçları ise, hürriyeti bağlayıcı ceza gerektiren adli yargının görev alanına giren suçlardır. VUK'da yer alan kaçakçılık, vergi mahremiyetini ihlal ve mükellefin özel işlerini görme fiilleri vergi suçlarındandır.

Hapis cezası öngörülen suçlar daha ağır nitelikte aykırılık oluşturan eylemlerdir. Ancak, bu suçlar için ceza mahkemelerince cezaya hükmedilmesi, bu eylem hakkında ayrıca idari yaptırımların uygulanmasına engel teşkil etmez (Karakoç, 2011: 494).

Vergi suç ve kabahatlerinde de ceza hukukunun temel ilkesi olan kanunilik ilkesi esastır. Böylece idarenin keyfi ve takdiri uygulamalarının önüne geçilmiş olur. Kanunilik ilkesinin sonucu olarak kıyas yasağı da söz konusudur. Bu durumda, gerek idari organlar gerek yarg1 organları yorum yaparak kıyasen suç ve ceza meydana getiremez (Altundiş, 2007: 169). Diğer bir deyişle idare düzenleyici işlemlerle suç ve ceza oluşturamaz aksi halde bu anayasaya aykırılık teşkil eder ${ }^{4}$. Zaten, Anayasa'nın 38. maddesinde yer alan, "İdare, kişi hürriyetinin kısıtlanması sonucunu doğuran bir müeyyide uygulayamaz" hükmüyle bu durum vurgulanmıştır.

\section{Vergi Kaçakçılığı Suçları}

Kamu harcamalarının en büyük finansman aracı olan vergiler mükellefler açısından, devletle aralarındaki gönülsüz ilişkiye dayanmaktadır. Anayasa'nın 73. maddesinde de belirtilen gibi "herkes, kamu giderlerini karşılamak üzere, mali gücüne göre, vergi ödemekle yükümlüdür." Ancak bu yükümlülük tek taraflı olduğu için, mükellefler bakımından bir yük olarak algılanmakta ve onları vergiden kaçınma yolları aramaya sevk etmektedir.

Mükelleflerin vergi ödemek istememelerinin çeşitli sebepleri mevcuttur. Bunlar, mükellefin ekonomik durumu, vergi sisteminin karmaşıklığı, vergi idaresine güvensizlik, kamu hizmetlerinin yetersizliği, vergi ahlakı gibi faktörlerdir.

\footnotetext{
${ }^{3}$ Resmi Gazete Tarih: 12.10.2004, Sayı: 25611 (Çalışmamızda bundan sonra bu kanun “TCK” olarak ifade edilecektir.)

${ }^{4}$ Anayasa Mahkemesi, 2010/19 E., 2011/6 K., 6.1.2011.
} 
Kişilerin satın alma güçlerini azaltan bu yükten kurtulma çabası içinde olan mükellef vergiden kaçınma yoluna gidebileceği gibi vergi kaçakçılığını da seçebilir. Vergiden kaçınma, vergi ödememek için yasal sınırların içinde hareket edilmesidir. Burada mükellef, vergiyi doğuran olayı hiç gerçekleştirmeyebileceği gibi bazı hukuk boşluklarından faydalanarak da vergi ödemekten kurtulabilir. Dolayısıyla bir hukuka aykırılık söz konusu olmadığı için suç oluşmaz.

Vergi kaçırma ise, yasalara aykırı şekilde hareket ederek vergi ödememek veya daha az ödemektir. Vergiden kaçınmadan ayrılan noktası burada hukuka aykırılığın söz konusu olmasidir.

VUK'da düzenlenen vergi kaçakçıllğı suçu ile korunan yarar, hazine gelirleri yani kamu yararı olsa da aynı zamanda kamu güveni sebebiyle kamu düzeni de sağlanacağından, bu suçun işlenmesiyle bu yararlar da ihlal edilmiş olmaktadır (Uğur ve Elibol, 2015: 85).

Devlet, vergi kayıplarını önlemek için bir takım teşviklerde bulunduğu gibi, bazı yaptırımlar da uygulamaktadır. Yasalarda vergi kaçakçılığının genel bir tanımı mevcut değildir. Ancak vergi kaçırmaya yönelik bazı fiiller VUK'da vergi kaçakçılığı suçu olarak düzenlenmiştir. VUK'un "Kaçakçılık Suçları ve Cezaları" başl1klı 359. maddesine göre,

a) Vergi kanunlarına göre tutulan veya düzenlenen ve saklanma ve ibraz mecburiyeti bulunan;

1) Defter ve kayltlarda hesap ve muhasebe hileleri yapanlar, gerçek olmayan veya kayda konu işlemlerle ilgisi bulunmayan kişiler adına hesap açanlar veya defterlere kaydı gereken hesap ve işlemleri vergi matrahının azalması sonucunu doğuracak şekilde tamamen veya klsmen başka defter, belge veya diğer kayıt ortamlarına kaydedenler,

2) Defter, kaylt ve belgeleri tahrif edenler veya gizleyenler veya muhteviyatı itibariyle yaniltıcı belge düzenleyenler veya bu belgeleri kullananlar,

Hakkında on sekiz aydan üç yıla kadar hapis cezasına hükmolunur. Varlığı noter tasdik kayttları veya sair suretlerle sabit olduğu halde, inceleme sirasinda vergi incelemesine yetkili kimselere defter ve belgelerin ibraz edilmemesi, bu fikra hükmünün uygulanmasında gizleme olarak kabul edilir. Gerçek bir muamele veya duruma dayanmakla birlikte bu muamele veya durumu mahiyet veya miktar itibariyle gerçeğe aykırı şekilde yansıtan belge ise, muhteviyatı itibariyle yanıltıcı belgedir.

b) Vergi kanunlar uyarınca tutulan veya düzenlenen ve saklama ve ibraz mecburiyeti bulunan defter, kaylt ve belgeleri yok edenler veya defter sahifelerini yok ederek yerine başka yapraklar koyanlar veya hiç yaprak koymayanlar veya belgelerin asll veya suretlerini tamamen veya klsmen sahte olarak düzenleyenler veya bu belgeleri kullananlar, üç yıldan beş yıla kadar hapis cezası ile cezalandırllır. Gerçek bir muamele veya durum olmadiğı halde bunlar varmıs gibi düzenlenen belge, sahte belgedir. 
c) Bu Kanun hükümlerine göre ancak Maliye Bakanlı̆̆ı ile anlaşması bulunan kişilerin basabileceği belgeleri, Bakanlık ile anlaşması olmadĭ̆ı halde basanlar veya bilerek kullananlar iki yıldan beş yıla kadar hapis cezası ile cezalandırllır.

371 inci maddedeki pişmanlık şartlarına uygun olarak durumu ilgili makamlara bildirenler hakkında bu madde hükmü uygulanmaz.

Kaçakçılık suçlarını işleyenler hakkında bu maddede yazılı cezaların uygulanması 344 üncü maddede yazılı vergi ziyaı cezasının ayrıca uygulanmasına engel teşkil etmez.

Anlaşıldığ1 üzere vergi kaçakçılığı suçu için, üç tip fiil grubu ve yaptırımı öngörülmüştür. Vergi kaçakçılığı suçu, her ne kadar TCK'da değil de VUK'da yer alsa da, genel ceza hukukunun genel ilke ve kuralları burada da uygulanır. Çünkü Anayasa'nın 5. maddesinde, "bu kanunun genel hükümleri özel ceza kanunları ve özel ceza içeren kanunlardaki suçlar hakkında da uygulanır" hükmüne yer verilmiştir.

Tüm suçlarda olduğu gibi vergi suçlarında da suçun oluşması bakımından gerekli olan bazı unsurlar söz konusudur. Bunlar kanuni unsur, maddi unsur, manevi unsur ve hukuka aykırılık unsurudur. Vergi kaçakçıllğı suçu için de bu unsurların incelenmesi gerekmektedir.

\section{Suçun Unsurları}

Suç için, ceza kanunlarında yer alan herhangi bir genel tanım mevcut değildir. Kanunilik ilkesinin bir sonucu olarak, kanunda her suç ayrı ayrı tanımlanmıştır. En genel anlamıyla suç, toplum tarafından onaylanmayan davranışların kanun tarafından düzenlenerek yaptırımlara bağlanmasıdır (Demirbaş, 2016: 197-198).

Suçun oluşumu bazı şartlara bağlıdır. Bunlar suçun unsurları olarak adlandırılmaktadır. Suçun unsurları, genel olarak her suçta bulunması gereken unsurlardır. Bu unsurlar bulunmadığı taktirde suç oluşmaz. Türk doktrininde kabul edilen unsurlar, kanuni unsur, maddi unsur, manevi unsur ve hukuka aykırılıktır (Demirbaş, 2016: 206). Bir fiilin suç olarak nitelendirilebilmesi için öncelikle kanuni unsur denilen objektif tipikliğin bulunması gerekir. Yani suçun tanımı kanunda açıkça belirtilmelidir. Kanunilik ilkesinin de bir sonucu olarak, kanunda bulunmayan bir eylemden dolayı kimse cezalandırılamaz. Bilindiği gibi kanunsuz suç ve ceza olmaz. Bir diğer unsur olan maddi unsura göre ise, tipikliğe uygun olarak gerçekleştirilen hareket ve neticenin olması gerekir. Ayrıca bunlar arasında da illiyet bağı bulunması gerekir. Hukuka aykırılık unsuru ise, suç tipini ihlal eden eylemin sadece ceza hukukuyla değil, tüm hukuk düzeni ile çelişki içinde bulunmasıdır (Demirbaş, 2016: 263).

Bu çalışmada, vergi kaçakçılığı bakımından özellikle manevi unsur üzerinde durulacağı için manevi unsur hakkında bilgi vermek gerekir. 


\subsection{Manevi Unsur}

Kanundaki kalıba uyan bir eylemin varlığının yanında bu eylemin failin kusurlu iradesi sonucu ortaya çıkmış olması gerekir (Şenyüz, 2015: 22). Yani gerçekleştirilen eylemin bir suç olarak nitelendirilebilmesi için bunun sadece maddi olarak gerçekleştirilmesi yeterli değildir. Söz konusu eylemin faile bağlanabilmesi için arada psişik bir bağın varlığı gerekir. Fiil ile fail arasındaki bu psikolojik bağ suçun manevi unsurunu ifade eder (Toroslu, 2009: 171).

Manevi unsur, sübjektif tipe uygunluk olarak da zikredilmektedir. Kişinin gerçekleştirdiği eylemden sorumlu tutulabilmesi için, eylemi yaptığı sırada iradesinin kusurlu olması şarttır. Kusur yoksa sadece hareket tipe uygun diye ceza verilmez. Bu sebeple kusurluluğu ortadan kaldıran haller söz konusuysa fail cezalandırılmaz. Vergi hukukunda sık rastlanıldığı için örnek vermek gerekirse mücbir sebep halinde elde olmayan dış bir sebep tarafından hareket yönlendirildiği için ceza verilmez (Şenyüz, 2015: 22-23).

Ceza hukukunda manevi unsur, kast ve taksir olarak ifade edilmektedir. TCK'nın 21/1 maddesinde "suçun oluşması kastın varlı̆̆ına bağlıdır" ifadesi ile kişinin cezalandırılabilmesi, eylemin kasten işlenmiş olması şartına bağlanmıştır. Yani ceza hukuku bakımından temel kusurluluk şekli "kast”"tır. Aynı maddede kastın tanımı, “...suçun kanuni tanımındaki unsurların bilerek ve istenerek gerçekleştirilmesidir" şeklinde yapılmıştır (İçel, 2007: 62). Kast hususunda Yargitay'in da buna benzer tanımlamaları mevcuttur'. Kast, öngörülen ve suç olarak kabul edilen bir fiili gerçekleştirmeye yönelen irade yani suç tipindeki unsurların bilinmesi ve istenmesi olarak da tanımlanabilir (Demirbaş, 2016: 367).

Özetle; kastın, bilmek ve istemek olarak iki unsurunun bulunduğu ifade edilebilir. Öncelikle failin kasten hareket ettiğinin kabul edilebilmesi için, kanuni tanımda yer alan hareket, netice ve nedensellik bağ 1 da dahil olmak üzere tüm unsurları bilmelidir. Bilinmesi gereken unsurlar her suç tipine göre değişse de, fail genel olarak suç tipinde kendisi ve mağdurla ilgili özellikleri, hareketin konusunu ve buna ilişkin özellikleri bilmesi gerekir (Özbek vd., 2010: 239-240). Ancak bu unsurlar sadece davranıştan önce var olan unsurlar değildir. Davranışla aynı zamanda ve davranıştan sonra var olan bu unsurlar da suçun varlığı için kurucu nitelikteyse fail tarafından bilinmesi gerekmektedir (Toroslu, 2009: 186).

\footnotetext{
5 “...Kast suçun maddi unsurlarını bilerek ve isteyerek gerçekleştirmesi olarak tanımlanmıştır. O halde bilme ve isteme kastın unsurlarıdır. Kast kişi ile işlediği maddi unsurları arasında psikolojik bağı da ifade etmektedir. Hareket ve kast birlikte olmalıdır. Failin iç dünyasını ilgilendiren kast failin iç dünyasını olay öncesi olay sırası ve olay sonrası davranışları ölçü alınarak belirlenmelidir. Sanığı harekete geçiren etken saik psişik olgunun irade aşamasıdır. Sosyal ilişkilerin ve dışa vurmuş hareketlerin disiplini olan hukuk, ceza normunun ihlaline etki yapmadıkça failin zihni ve ruhi durumu ile uğraşmaz. Suçun işlendiği zaman failin öngörü ve irade ile hareket etmiş olması yeterlidir. Failin iç dünyasını ilgilendiren kastın niteliğini belirleyebilmesi için dıș dünyaya yansıyan davranışlardan hareketle sonuç çıkarmak olanaklıdır..." Yargıtay 6. CD., 15535/2378, 15.02 .2012 (Malkoç, 2013: 212). “...5237 sayılı TCK'nun "Kast" başlıklı 21. maddesi; "(1) Suçun oluşması kastın varlığına bağlıdır. Kast, suçun kanuni tanımındaki unsurların bilerek ve istenerek gerçekleştirilmesidir. Maddenin 1. fikrasının ikinci cümlesinde doğrudan kast tanımlanmıș, Buna göre, doğrudan kast, öngörülen ve suç teşkil eden bir fiili gerçekleştirmeye yönelik irade olup, kanunda suç olarak tanımlanmış eylemin bilerek ve istenerek gerçekleştirilmesi ile oluşur. Fail hareketinin kanuni tipi gerçekleştireceğini bilmesi ve istemesi halinde doğrudan kastla hareket etmiş olacak...” Yargıttay CGK., 2014/200 E., 2016/250 K., 10.05.2016.
} 
Kastın bir diğer unsuru da istemektir. Gerçekleştirilen eyleme dair unsurların bilinmiş olması onun aynı zamanda isteneceği anlamına gelmez. Öngörülen unsurların fail tarafından istenmiş olması da gerekmektedir. Fail bilip öngördüğü sonuç için iradesini harekete geçirdiği zaman kast oluşmuş sayılır (İçel, 2007: 64). Görüldüğü gibi, kastın varlığ bakımından failde bilme ve isteme unsurlarının bulunması yeterlidir. Yani aslında faildeki saikin kanunda aksi belirtilmedikçe kastın kabulü üzerinde bir etkisi yoktur (Demirbaş, 2016: 369).

TCK'nın 21/2 maddesine yeni bir kast türü dahil edilmiştir. Buna göre, “kişinin, suçun kanuni tanımındaki unsurların gerçekleşebileceğini öngörmesine ră̆men, fiili işlemesi halinde olası kast vardır..." Olası kast durumunda, suç tanımındaki unsurlar fail tarafından öngörülmektedir ancak doğrudan kasttan farklı olarak bu unsurların gerçekleşmesi fail tarafindan muhakkak değil muhtemel olarak görülmektedir (Özgenç, 2009: 235). Yani, öngörü bulunmasına rağmen neticenin meydana gelmeme ihtimali de söz konusudur. Ancak fail, neticenin meydana gelebileceğini düşündüğünde "olursa olsun" diyerek kararından vazgeçmemektedir. Sonuca katlanmayı göze almaktadır (Malkoç, 2013: 214). Olası kast halinde, ağırlaştırılmış müebbet hapis cezasını gerektiren suçlarda müebbet hapis cezasına, müebbet hapis cezasını gerektiren suçlarda yirmi yıldan yirmi beş yıla kadar hapis cezasına hükmolunur; diğer suçlarda ise temel ceza üçte birden yarısına kadar indirilir (TCK 21/2).

Suçun kast dişındaki bir diğer manevi unsuru da taksirdir. Ceza hukukunda kast temel kusurluluk hali iken taksir istisnai bir nitelik göstermektedir. Çünkü, bir kişinin taksirli hareketi nedeniyle sorumlu tutulabilmesi için kanunda özel bir düzenleme bulunması gerekir (Demirbaş, 2016: 384-385). TCK'nın 22/2. maddesine göre "taksir, dikkat ve özen yükümlülüğ̈̈ne aykırıllk dolayıslyla, bir davranışın suçun kanuni tanımında belirtilen neticesi öngörülmeyerek gerçekleştirilmesidir." Yargıtay kararlarında da taksirin tanımı ve unsurlarına sıkça yer verilmiştir ${ }^{6}$. Taksirden söz edebilmek için öncelikle taksirle işlenebilen bir suç olmalı ve bu durum kanunda açıkça belirtilmelidir. Diğer unsur ise gerçekleştirilen hareketin iradi olmasıdır. Ancak bu iradilik sonuca yönelik olmamalıdır. Fail, icraî veya ihmali davranışı isteyerek yapmış olmalı ama meydana gelen sonucu istememiş olmalıdır. Taksiri kasttan ayıran en önemli özellik de budur. Ayrıca aynı şekilde taksirde de sonuç

\footnotetext{
6 "İstisnai bir kusurluluk şekli olan taksirde, failin cezalandırılabilmesi için mutlaka kanunda açık bir düzenleme bulunması gerekmektedir. TCK'nun 22/2. maddesinde taksir; "dikkat ve özen yükümlülüğüne aykırılık dolayısıyla bir davranışın, suçun yasal tanımında belirtilen neticesi öngörülmeyerek gerçekleştirilmesidir" şeklinde tanımlanmıştır. Ceza Genel Kurulunun birçok kararında vurgulandığı ve öğretide benimsendiği üzere, taksirli suçlarda bulunması zorunlu olan hususlar;

1- Fiilin taksirle işlenebilen bir suç olması,

2- Hareketin iradi olmas1,

3- Sonucun istenmemesi,

4- Hareket ile sonuç arasında nedensellik bağının bulunması,

5- Sonucun öngörülebilir olmasına rağmen öngörülmemiş olması, Şeklinde kabul edilmektedir.

Taksirli suçlarda, gerek icrai, gerekse ihmali hareketin iradi olması ve meydana gelen neticenin öngörülebilir olması gerekmektedir. İradi bir davranış bulunmadığı takdirde taksirden bahsedilemeyeceği gibi, öngörülemeyecek bir sonucun gerçekleşmesi halinde de failin taksirli suçtan sorumluluğuna gidilemeyecektir." Yargitay CGK., 2017/1-108 E., 2017/311 K., 06.06.2017.
} 
öngörülebilir olmalıdır. Ancak burada öngörülebilir olan sonucu fail öngörememiştir. Sonucun normalde öngörülebilir olması taksiri kaza ve tesadüften ayıran bir özelliktir (Çiftcioğlu, 2013: 325). Öngörebilmenin imkansız olması durumundan taksirden söz edilemez. Öngörebilmenin tespitinde ise, failin sosyal çevresi, mesleği, deneyimleri ve kişisel özellikleri gibi unsurlar rol oynamaktadır (Çiftçioğlu, 2013: 329). Taksirin bir diğer unsuru ise, dikkat ve özen yükümlülüğünün yerine getirilmemesidir. Bu yükümlülüklerin yazılı kurallar veya yazılı olmayan sosyal kurallar olması arasında fark bulunmamaktadır (Toroslu, 2009: 199). Taksire ilişkin son unsur olarak da hareket ile netice arasında bir nedensellik bağı bulunmasıdır.

TCK'nın 22/3. maddesinde "kişinin öngördüğ̈̈ neticeyi istememesine karşın, neticenin meydana gelmesi halinde bilinçli taksir vardır; bu halde taksirli suça ilişsin ceza üçte birden yarısına kadar artırılır" hükmüne yer verilerek bilinçli taksirin tanımı yapılmıştır. Bilinçli taksir, fail tarafından sonucun öngörüldüğü ancak istenmediği durumlarda söz konusu olmaktadır. Neticenin meydana gelebileceğini öngörmesine rağmen fail, aslında neticenin gerçekleşmesini istememektedir ve başka durumlara güvenerek neticenin meydana gelmeyeceği düşüncesiyle harekete devam etmektedir (Malkoç, 2013: 257). Fail burada daha çok kendi şansına, bilgi ve tecrübesine güvenmektedir. Zaman zaman olası kastla karıştırılsa da, olası kastla bilinçli taksiri ayıran en önemli nokta failin gerçekleşen neticeyi isteyip istememesidir. Olası kastta fail, gerçekleştirdiği eylemin sonucunda amaçladığı neticeden farklı olan diğer neticelerin gerçekleşebileceğini öngörmekte ancak bunlara kayıtsız kalarak adeta kabullenmektedir. Oysa bilinçli taksirde fail neticeyi öngörmesine rağmen bunun gerçekleşmesini istememekle birlikte gerçekleşmemesi için çaba da göstermektedir. (Demirbaş, 2016: 373). Olası kasttan farklı olarak fail öngördüğü sonucun gerçekleşmemesi için elinden gelen tüm çabayı göstermektedir. Yani, olası kasttaki kayıtsızlık durumu bilinçli taksirde söz konusu değildir (İçel, 2007: 65).

Bilinçli taksir, kanunda taksirin daha ağır şekli olarak yer almıştır. Çünkü, failin sonucu öngörmesine rağmen tehlikeli harekete devam etmesinde tedbirsizliğin daha büyük olduğu düşünülmüştür (Toroslu, 2009: 208).

Fail ile fiil arasındaki psikolojik bağı ifade eden ve suçun soyut unsurunu oluşturan manevi unsurun tespiti, fail kast-taksir derecesine göre cezalandırılacağı için yaptırım yönünden son derece önemlidir.

\section{Sahte ve Muhteviyatı İtibariyle Yanıltıcı Belge Düzenleme ve Kullanma Suçunda Manevi Unsur ve Tespiti}

213 sayılı Vergi Usulü Kanunu incelendiğinde vergi kaçakçıllı̆ı suçu için faille fiil arasındaki psikolojik bağ anlamına gelen manevi unsurun ayrıca düzenlenmediği görülmektedir. Bu durumda genel kanun niteliğinde olan TCK'nın 5. maddesi uyarınca, kanunun genel hükümlerinin, özel kanunlarda düzenleme bulunmayan konularda uygulanması gerekmektedir. Böylelikle vergi kaçakçılığının manevi unsuru açısından TCK'nın genel hükümler kısmına başvurulmaktadır. 
Türk Ceza Hukukunda bir suçun oluşması temel kusur şekli olan kasta bağlıdır. Yukarıda da bahsettiğimiz gibi, kast, suçu oluşturan hareketlerin ve sonucunun bilerek ve istenerek ortaya çıkması anlamına gelmektedir (Karakoç, 2011: 499).

Vergi kaçakçıllğı suçuyla, sahte veya muhteviyatı itibariyle yanıltıcı belge düzenleme ile kullanma fiilleri arasında yaptırım olarak bir fark öngörülmemiştir. Ancak, sahte veya muhteviyatı itibariyle yanıltıcı belge düzenleme eyleminde ayrıca kast aramaya gerek olmadığı, kastın varlığının karine olduğu kabul edilmektedir (Arslaner, 2017: 122). Çünkü kişi, ortada gerçek bir mal ve hizmet teslimi olup olmadığını veya içeriğinin farklı olduğunu bilmeden bu belgeyi düzenleyemez. Ancak, sahte fatura "bilmeden" kullanılmış olabilir (Aslanpınar, 2011). Düzenleme fiili bakımından manevi unsurun "kast" olduğu hususunda tereddüt yoktur ${ }^{7}$. Bilmeden ve istenmeden söz konusu belgelerin düzenlenmesi mümkün görünmemektedir. $\mathrm{Bu}$ şekilde belge düzenleyenlerin cezalandırılması hususunda şüphe yoktur (Ürel, 2015: 849). Fakat düzenleme eyleminin de suç oluşturabilmesi için, sahte belge düzenlendiğinin somut şekilde ispat edilmesi gerekir. Örneğin Yargitay, birkaç kez sahte fatura düzenleyen şirketin tüm faturaları sahte düzenlediği yönünde bir varsayıma gidilemeyeceği yönünde karar vermiştir ${ }^{8}$.

Ayrıca, sahte fatura düzenlediği iddia edilen kişinin mükellef olarak kaydının bulunmaması, adresinde bulunmaması, adresin başkasına ait olduğu tespit edilmesi, işini terk ettiği halde bastırdığı faturaları iptal ettirmemesi gibi haller faturaların gerçek alım ve satım veya hizmete dayalı olarak düzenlenmediğini gösterir (Parlar ve Demirel, 2002: 355).

VUK'da 4369 sayılı kanunla getirilen yapılan değişiklikle, sahte ve muhteviyatı itibariyle yanıltıcı belge kullanma fiilleri için kanunda daha önce yer alan "bilerek" ibaresi çıkarılmıştır. Böyle bir değişikliğin yapılması suçun manevi unsuru açısından farklı yorumlara yol açmıştır. Kanunun yeni metninde söz konusu fiiller için "bilerek" ifadesine yer verilmemesi bu suç bakımından kusursuz sorumluluğun kabul edildiği yönünde görüşlere sebep olmuştur (Öncel vd, 2013: 213). Bu tereddütlerin ortadan kalkması için bu ibarenin yeniden kanunda yer alması hususunda kanun teklifi bile sunulmuştur (Özyer, 2015:1010).

Kanun koyucunun iradesini anlamak için 4369 sayılı kanunla yapılan değişikliğin gerekçesine ${ }^{9}$ bakıldığında failin bu eylemleri iradi olarak yani kasdi olarak işleyip

\footnotetext{
7 “...213 sayılı Vergi Usul Yasasının 01.01.1999 tarihinde yürürlüğe giren 4369 sayılı Yasa ile değişik 359/b-1 maddesine göre, vergi kanunları uyarınca düzenlenmesi gereken belgelerin "sahte olarak düzenlenmesi" suçun oluşumu için yeterli olup bu belgelerin kullanılması ve vergi ziyaı doğması suçun unsurları olmaktan çıkarıldığ cihetle; Korteks isimli şirketin sahibi olan sanığın 31.03.2005 ve 20.10.2005 tarihli irsaliyeli faturaları sahte olarak düzenleyerek katılan şirket hakkında icra takibi başlattığının iddia olunması karşısında, eylemin sübutu halinde Vergi Usul Kanununun 359/b-1 maddesinde düzenlenen "sahte fatura düzenlemek" suçunu oluşturacağ1..." Yargitay 11. CD , 2013/2081 E., 2014/4921 K., 17.03.2014.

8 “Olayda, her ne kadar (...) Ltd. Sti. ve Tasfiye Halinde (...) Ltd. Sti. hakkında yapılan tespitlere göre, anılan şirketlerin sahte fatura düzenlediği konusunda kuşkular bulunmakta ise de, anılan şirketlerin düzenlediği tüm faturaların sahte olduğu seklinde bir genelleme yapılması mümkün olmayıp, anılan şirketlerin davacı adına düzenlediği faturaların sahte ve muhteviyatı itibarıyla yanıltıcı olduğu hususunun açık ve somut bir şekilde ortaya konulmas1 gerekmektedir...” Yargitay 9. D , 2008/7281 E., 2012/2865 K., 23.05.2012.

9 “... Bilindiği gibi genel olarak hukukta cezayı gerektiren fiillerde aranan temel öğe bu fiillerin kasıt unsuru taşıyıp taşımadığıdır. Kasıt unsuru, fiili cürüm haline çevirir. Kastın söz konusu olmadığı hallerde kabahatten ve kusurdan (taksirden) söz edilebilir.
} 
işlemediğinin manevi unsur olarak kabul edilmesi gerektiği anlaşılmaktadır (Parlar, 2002: 353).

Gerçekten de kanunun gerekçesinden de anlaşıldığ kaldırmak değildir. Kasıt unsuru yoksa fiil suç teşkil etmeyecektir. Buna ilişkin, Maliye Bakanı tarafından bütçe komisyonunda verilen bir örnek söz konusudur. Buna göre bir tacir, o işi yaptığı bilinen piyasada faal olan birinden mal almıştır. O kişi de kendi faturasını değil de bastırdığı faturayı vermiş̧tir. Bu durumda alışveriş gerçek olduğundan ve alıcı sahteliği bilmediğinden suç olmayacaktır (Baykara, 3). "Bilerek" ifadesinin kanun metninden çıkarılması ile sadece ispat yükünün tersine çevrildiği böylelikle bu düzenlemeye göre üç kat vergi ziyaı cezasının kesilebilmesi için sadece belgenin niteliğinin kanıtlanmasının yeterli olacağı, vergi kaçırma kastının ispatının gerekmediği ifade edilmektedir. Ancak cezanın muhatabı daha sonra bir idari dava açarsa, söz konusu belgeyi bilerek kullanmadığını ispatlama imkanı vardır (Candan, 2010: 160).

4369 sayılı kanunla yapılan bu değişiklikten sonra yaşanan tartışmalara son vermek amacıyla Maliye Bakanlığı tarafından 306 sayılı VUK Genel Tebliği yayınlanmıştır. Söz konusu tebliğde ${ }^{10}$, "bilerek" kelimesinin yasa metninden çıkarılmasını suçun kasten işlenebilir suç olma özelliğini kaybettirmediği açıklanmıştır (Taştan, 2014: 212). Yine bu tebliğde, "bilme" kavramının takdiri herhangi bir objektif ölçüte bağlamaksızın vergi inceleme elemanlarına bırakılmıştır (Ağar, 2005: 286). Buna göre, vergi inceleme elemanları mükellefin bu belgelerin bilerek kullanıldığı sonucuna varırsa vergi suçu raporu düzenleyerek suç duyurusunda bulunacaktır. Ayrıca bu genel tebliğde, bilmeden kullanma fiili sonucunda bir vergi ziyaı ortaya çıkarsa bunun üç kat değil bir kat olarak uygulanması gerektiği belirtilmiştir.

Görüldüğü gibi, idare suçun oluşması açısından kastın varlığını aramaktadır. Yani "bilerek" ibaresi çıkarılmış olsa dahi genel olarak suç teorisi çerçevesinde suçun manevi unsuru "kast" olduğu için, bu belgelerin bilerek kullanılmadığı durumlarda suçun oluşmayacağı görüşündedir. Yargı kararlarında da bu konuya ilişkin örnekler mevcuttur. Yüksek mahkeme

$\mathrm{Ne}$ var ki, bazı fiiller doğrudan mali sistemin, belge düzeninin ve mali otoritenin zayıflamasına ve hatta çökertilmesine yönelik, bireysel veya örgütsel suç niteliğinde olabilir. Muhasebe hileleri, defter ve belgelerin gizlenmesi ya da yok edilmesi, denetim ve kontrolden kaçınmak amaçlı davranışlar ve sahte ve içerik açısından yanıltıcı belge düzenleyip kullanmak gibi fiiller bu kategoride sayılabilir. Bu nevi fiillerin ortak özelliği niyet, amaç ve plan unsurunu taşımalarıdır. Bu üç unsur fiilde kastın varlığını ortaya koyar. Yapılan bu düzenleme ile kasıt unsuru taşıyan ve aynı zamanda nitelikli olan fiiller ile kabahat veya kusur sayılabilecek fiillerin ceza sistematiği değiştirilmekte, fiillere karşılık tertip olunan cezaların mahiyetleri farklılaștırılmaktadır."

${ }^{10}$ Resmi Gazete Tarih: 18.06.2002, Sayı: 24789. “...Sahte veya muhteviyatı itibariyle yanıltıci belgenin gerek düzenlenmesinin gerekse kullanılmasının kaçakçılık suçunun oluşması yönünden ayrı ayrı değerlendirilmesi gerektiği sonucu ortaya çıkmaktadır. Sahte veya muhteviyatı itibariyle yanıltıcı belge düzenlenmesi, kastın karinesi olup, bunun ayrıca değerlendirilmesine gerek bulunmamaktadır. Ancak gerçekte yapılan bir mal veya hizmet alamı karșılığında mal veya hizmeti sağlayan tarafından kendi belgesi yerine bir başka mükellefin belgesi verilebilmektedir. $\mathrm{Bu}$ gibi durumlarda iş veya hizmetin mahiyetine göre belgeyi alan tarafin bu belgenin mal veya hizmetin sağlandığı mükellefe ait olup olmadığını bilemediği durumlar söz konusu olabilmektedir. Bu gibi durumlarda sahte belgeyi kullanmıș olan mükellefin, bu belgenin satın aldığ mal veya hizmeti sağlayana ait olmadığını bilip bilmemesi önem taşıyacaktır. Sayet kullanıcının belgenin sahte olduğunu bilmesi gerekiyorsa, bir başka deyimle, kasıt söz konusu ise burada 359 uncu maddede belirtilen anlamda bir sahte belge kullanımı söz konusu olacaktır. Aksi takdirde ise suçun manevi unsuru oluşmadığından durum madde kapsamında değerlendirilemeyecektir..." 
de genel olarak bu belgeleri kullanma suçu açısından kastın aranması gerektiği yönünde kararlar vermiştir. Bir kararında, muhteviyatı itibariyle yanıltıcı belge olduğu saptanan faturanın bilmeden kullanıldığı sonuç ve kanaatine vararak cezada indirime gitmiştir ${ }^{11}$.

Aslında kaçakçılık suçlarının bilmeden işlenmesi çok da kolay değildir. Örneğin, hiçbir alışveriş olmadan belge alıp deftere işlemek çok da mümkün görünmemektedir. Ancak, günümüzde satıcı tarafından alıcıya başka birine ait belge verilmesi yaygındır. İşte bu gibi durumlarda satıcı o belgenin başkasına ait olduğunu bilmiyorsa kasıt olmadığından dolayı ceza verilemeyecektir (Şenyüz, 2015: 467; Arslaner, 2017: 122).

Suçun diğer unsurlarına göre manevi unsurun varlığının tespiti daha zordur. Çünkü manevi unsur failin iç dünyasıyla ilgilidir. Bu sebeple, bu unsurun kanıtlamaya elverişli kanıtlarla araştırılarak takdir edilmesi gerekmektedir. Bu takdir yapılırken de müvekkilin basiretli bir tüccar gibi davranıp davranmadığının, belgenin sahte olup olmadığını veya gerçek mahiyetini anlayabilecek durumda olup olmadığının araştırılması gerekir. Manevi unsur olarak kast aranırken, eğer belgeyi kullanan kişi basiretli bir tüccar gibi yeterli ve dikkatli özeni gösterdiğinde belgenin sahte olduğunu bilebilecek ve anlayabilecek durumda olmas1, belgeyi gerçek mahiyetini bilerek kullandığı sonucunu verir (Parlar ve Demirel, 2002: 353). Mal ve hizmet satın almadığı halde mal satışına ilişkin faturayı kendi defter ve kayıtlarına işleyen mükellef için bu faturanın sahte olduğunu bildiği kabul edilmelidir. Ayrıca yine ispat bakımından, vergi incelemesi sırasındaki kabul ve ikrarı, faturayı düzenleyen ve üçüncü kişilerin ifadesi gibi haller suçun oluştuğuna dair kanıt oluşturur (Parlar ve Demirel, 2002: 353). Güçlü kanıtlar söz konusuysa failin, soyut şekilde belgenin sahteliğini bilmeden kullandığı yönündeki ifadeleri soyut inkar olarak kabul edilmelidir ${ }^{12}$. Genelde mükelleflerin bilmeme yönündeki iddiaları suçtan kurtulmak için bahane amaçlı bir savunma olarak görülmektedir. $\mathrm{Bu}$ sebeple son zamanlarda gerek inceleme elemanları gerekse yarg1 kararlarında bu tür savunmalara pek rağbet gösterilmemektedir (Aktaş, 2009).

\footnotetext{
11 “...Davacı tarafından katma değer vergisi indiriminde kullanılan ancak muhteviyatı itibariyle yanıltıcı olduğu saptanan fatura bedellerinin büyük bir kısmı karşılığında davacı tarafından çek düzenlenmesi ve bu durumun da inceleme elemanına belirtilmesi nedeniyle davacı ihtilaflı faturalar karşılığında gerçekten mal aldığı, ancak muhteviyatı itibariyle yanıltıcı olduğu saptanan bu faturaların bilmeden kullanıldığı sonuç ve kanaatine varıldığından, cezanın bir kata indirilmesi gerekirken, üç kat olarak onanmasında isabet görülmemiştir." Danıştay 9. D , 2009/1991 E., 2010/267 K., 27.01.2010. Aynı yönde bkz. Danıştay 9. D , 2009/2070 E., 2010/269 K., 27.01.2010

12 “... faturaları düzenleyen ... ve ... arasında gerçek bir mal alış verisinin bulunmadığı, faturaların gerçek bir muamele veya duruma dayanmadığı, alınan faturaların yevmiye defterine gider olarak kaydedilmesi ve KDV indiriminde kullanılması nedeniyle vergi ziyaına neden olunduğu, sanık tarafindan sahte faturaların bilerek kullanılmadığı savunulmuş ise de; faturaların sayısı, miktarı, alındıkları firmaların farklılıkları, bu firma ve kişilerle gerçek bir mal ve hizmet alışverişinin olmaması birlikte değerlendirildiğinde, savunmanın dosya içeriğine uygun olmayıp, soyut inkardan ibaret olduğu, ayrıca Yerel Mahkemece Danıştay incelemesinden geçmek suretiyle kesinleşen vergi mahkemesi kararlarına dayanılarak beraat kararı verilmiş ise de; bu eylemler nedeniyle vergi kaybına neden olunduğunun, kesinleşen vergi mahkemesi kararları ile de saptandığı, <faturaların bilerek ve istenerek kullanılmadığı yönündeki gerekçenin suçun manevi ögesiyle ilgili olduğu ve oluşup oluşmadığının ceza mahkemesince değerlendirileceği, toplanan kanıtlardan sanığın 1995 ve 1996 yıllarında sahte faturaları bilerek kullanmak suretiyle vergi kaybına neden olduğu, atılı suçun tüm ögeleriyle oluştuğu anlaşılmaktadır." Yargıtay CGK, 2001/11-213 E., 2001/219 K., 16.10.2011. Aynı yönde bkz, Yargıtay 11. D , 2002/5109 E., 2002/6193 K., 24.06.2002.
} 
Sahte veya muhteviyatı itibariyle yanıltıc1 faturanın bilerek kullanılmasının tespitinde kullanılan argümanlar arasında bu belgelerin toplam alışlar içerisindeki oranı da büyük rol oynamaktadır. Hangi oranda kullanılırsa bilerek kullanmış sayılacağ 1 hususunda bir yasal düzenleme söz konusu değildir. Bu belgeleri kullanma sıklığı, değer olarak yüksekliği, işletmenin toplam iş hacmi içerisindeki oranı genelde kasten kullanılıp kullanılmadığı hususunda bilgi verir (Işık, 2013). Bilerek kullanmanın tespitinde 84 sayılı KDV Genel Tebliği'nin “Olumsuz Rapor" başlıklı maddesinde "sahte ve muhteviyatı itibariyle yanıltıcı belge kullanıldığ konusunda belirlemelerin yer aldiğı raporlarda, raporun ait olduğu her bir vergilendirme döneminde sahte ve muhteviyatı itibariyle yanıltıcı belge kullanılması nedeniyle reddedilen katma değer vergisi iade alacağının, iade hakkı doğuran işlem dolayısıyla yüklenilen verginin (ihraç kaydlyla teslimlerde teslim bedeli üzerinden hesaplanan verginin, iade hakk doğuran işlemi bulunmayan mükelleflerde ilgili dönemdeki toplam vergi indiriminin) \% 5'ini aşması halinde bu rapor olumsuz rapor sayılır" şeklinde bir ifade söz konusudur. Yani bu durumda, vergi idarelerinin sahte faturanın bilerek kullanılması konusunda, idari olarak \% $\%$ 'lik bir sınır öngörmüş olduğu anlaşılmaktadır (Iş̧1k, 2013).

Belgenin bilerek kullanılmasına ilişkin Yargıtay Ceza Kurulu tarafından verilen bir kararda ${ }^{13}$ da, "vergi ziyaina sebebiyet verecek biçimde tahrif edilmiş veya sahte olarak düzenlenmiş birçok belgeyi kullanan kişinin bu belgelerin niteliğini bildiği kabul edilir" denilerek ticari faaliyet gösteren mükelleflerin muhasebe hizmetleri verenlerle sıkı işbirliğinde bulunulduğu düşünülerek belgelerin gerçek mahiyetini veya sahte belge olduğunu bilmedikleri iddiasının ticari teamüllere uygun olmayacağı yargısında bulunulmuştur (Aktaş, 2009).

Ceza hukukunda geçerli olan resen araştırma ilkesi gereği kastın bulunup bulunmadığı hususunu mahkeme kendisi araştıracak ve bir kanaate varacaktır. Araştırma sırasında, vergi idaresi tarafından düzenlenen tutanaklar kanıt bakımından önemli yere sahiptir (Parlar ve Demirel, 2002: 354).

Vergi kaçakçıllğı suçunu olası kast bakımından değerlendirmek gerekirse, bu suçun olası kastla da işlenebileceği kabul edilmektedir. Çünkü kasten işlenebilen suçlar hem doğrudan hem olası kastla işlenebilir. Ancak "bilerek" ifadesinin yer aldığı suçların sadece doğrudan kastla işlenebileceği ifade edilmektedir. Dolayısıyla kaçakçılık suçunun oluşması için olası kastın varlığ 1 yeterli görülmelidir (Özyer: 2015: 1013).

Vergi kaçakçılığı suçundaki kast, genel kast olarak anlaşılmalıdır. Yani kanunda failin özel saikle hareket etmesi aranmamıştır. Suçun oluşması için fiilin bilerek ve istenerek gerçekleştirilmesi yeterlidir. Vergi kaçakçıllğg suçlarında vergi zıya1 gibi özel bir kast öngörülmemiştir (Saban, 2006: 257).

Suçun diğer manevi unsuru olan taksirin de kaçakçılık suçu açısından değerlendirilmesi gerekir. Taksirle işlenen suçların kanunda ayrıca ve açıkça tanımlanmış olması gerektiğinden vergi kaçakçılı̆g 1 suçunun da taksirle işlenmesi söz konusu değildir. Yani failin eylemi taksirli bir eylem ise bu suç oluşmayacaktır (Ağar, 2005: 280; Karakoç, 2016: 301).

\footnotetext{
${ }^{13}$ Yargitay CGK, 1985/9-462 E., 1986/125 K., 17.03.1986.
} 
Kaçakçılık suçu için aranan eylemlerden bir diğerini oluşturan 359/c'de Maliye Bakanlı̆̆ ile anlaşması olmadığı halde belgeleri basma veya "bilerek" kullanma eylemindeki bilerek ifadesi hala geçerlidir. Ancak bu ifade olmasa bile, suçlar için temel kusurluluk hali kasttır. Sahte veya yanıltıcı belge kullanılmasında "bilerek" ibaresine yer verilmezken Maliye Bakanlığı ile anlaşması olmadığı halde belge basanların vereceği belgeleri kullananlar bakımından söz konusu ibarenin hala kanun metninde yer alması yeni tartışmalara yol açabilir (Özyer, 2015: 1023). Yani, kanunun lafzından yola çıkarak kastın varlığını sadece yetkisiz belge basmak ve kullanmak fiilleri için aramak yanlış bir değerlendirme olacaktır (Arslaner, 2017: 117).

\section{Sonuc}

Devletin sosyal düzeni korumak amacıyla bazı kamu harcamaları yapması gerekmektedir. Bunların finansmanını da büyük ölçüde egemenlik gücüne dayanarak koyduğu vergiler ile sağlamaktadır. Mükellefler, malvarlıklarına müdahale niteliğindeki bu vergilere karşı direnç gösterip kurtulma yolları aramaktadır. Vergiye gösterilen en yaygın tepki vergi kaçırma olarak karşımıza çıkmaktadır. Bu sebeple vergi kaçakçılığı sayılabilecek fiiller suç olarak tanımlanıp yaptırıma bağlanmıştır.

Vergi kaçakçılığı suçları, VUK'da düzenlenmiştir. Manevi unsur bakımında vergi kaçakçılığı suçları için de ceza hukukun temel kusurluluk şekli olan kast geçerlidir. 4369 sayılı Kanunla, sahte belge ve muhteviyatı itibariyle yanıltıcı belge kullanma fiillerinde, "bilerek" ifadesi kaldırılmıştır. Bu değişiklikle, suçun oluşması için kast unsurunun aranıp aranmayacağı gündeme gelmiştir. Ancak bu ifadenin kalkması kast aranmasına engel değildir. Çünkü, suç genel teorisi ve suçun unsurları kapsamında bakıldığında kast her suç tipi için genel kusurluluk şeklidir ve içinde bilme ve isteme unsurlarını taşır. Kanun koyucunun maddenin ilk halinde bile "bilerek" ifadesine yer vermesine gerek olmadığ görüşündeyiz. Ancak madde metninde yer verdiği bu ifadeyi daha sonra metinden çıkarmasaydı bu tür tartışmalara mahal vermemiş olacaktı. Zira, manevi unsur bakımından bakıldığında yapılan değişiklik pratikte bir şey ifade etmemektedir. İdare ve yargı kararları da bunu desteklemektedir. Aksini düşünmek ceza hukukunun temel ilkelerine ve suç genel teorisine aykırılık teşkil eder.

Kastın tespiti bakımından ise önem taşıyan nokta, düzenleyici işlemlerle bu tespitin idareye bırakılamayacağıdır. Dolayısıyla yetkili makamlar, vergi inceleme elemanlarının suç duyurusunu beklemeksizin ve onların takdiriyle bağlı kalmaksızın resen araştırma ilkesi gereğince kendiliğinden harekete geçebilmeli ve değerlendirme yapabilmelidir.

Özetle, 4369 sayılı Kanunla "bilerek" ifadesinin kaldırılması yerinde bir düzenleme olmamıştır. Çünkü kanun gerekçesinde ve yayınlanan genel tebliğle yasa koyucunun gerçek amacının anılan belgeleri bilmeden kullananları da cezalandırmak olmadığı anlaşılmaktadır. O sebeple böyle bir değişiklik sadece tartışma yaratmaktan öteye gidememiştir. Şayet yasa 
koyucunun amacı bilmeden veya gerekli özeni göstermeden kullananları cezalandırmak ise o zaman bu suçu taksirle işlenebilen bir suç haline getirmesi yeterli ve daha yerinde olurdu.

Çalışmamızın da çıkış noktası olan 4369 sayılı Kanun değişikliğiyle suçun kast unsuru ortadan kalkmış olmamaktadır. Bu suçun manevi unsuru hala "kast"tır. "Taksir" ise mutlaka yasada belirtilmesi gereken kusur şeklidir. Bu sebeple vergi kaçakçılığı için ayrıca taksirle işlenebilir gibi bir ifade bulunmadığı için, bu suç taksirle işlenemez. 


\section{Kaynakça}

AĞAR, S. (2005), "Sahte veya Muhteviyatı İtibariyle Yanıltıcı Belge Düzenleme veya Kullanma Suçu”, TBB Dergisi, Yı1: 18, S: 58, 273-301.

AKTAŞ, R. (2009), "Bilmeden ve İstemeden Vergi Kaçırmak M1", http://www.muhasebenet.net/makale_ramazan\%20aktas-

bilmeden\%20ve\%20istemeden\%20vergi\%20kacirmak\%20mi.html, Erişim Tarihi: 29.11.2016

ALTUNDİş, M. (2007), “Vergi Usul Kanunu’nda Yer Alan Vergi Suç ve Cezaları ile Yeni Türk Ceza Kanunu'nun bu Suçlara Etkisi”, Ankara Barosu Dergisi, Y11: 65, S: $1,168-179$.

ARSLANER, H. (2017), Vergi Kabahat ve Suçlarının Unsurları, Bursa: Ekin.

ASLANPINAR, B. (2011), "Naylon Fatura Kullanma Suçunda Kasit Unsuru ve İspat Külfeti”, Yaklaşım Dergisi, Y11: 2011-Mayıs, Sayı: 221.

BAYKARA, B. "Vergi Kaçakçılı̆̆ı Suçunda Kast Unsuru Kaldırıldı Mı?", www.baykaraymm.com/.../vergi_kacakciliginda_kast_kaldirildi_mi.doc, Erişim Tarihi: 10.12.2016

CANDAN, T. (2010), Vergi Suçları ve Cezaları, Ankara: Maliye ve Hukuk Yayınları.

ÇífTCioĞLU, C. T. (2013), Türk Ceza Kanunu'nda Taksir, Ankara Barosu Dergisi, S: 3, 317-338.

DEMİRBAŞ, T. (2016), Ceza Hukuku Genel Hükümler (11. Baskl), Ankara: Seçkin.

EDİZDOĞAN, N., TAŞ, M., ÇELİKKAYA, A. (2007), Vergi ceza ve Yargılama Hukuku, Bursa: Ekin.

IŞIK, E. (2013), “Bir Takvim Yılında Birden Çok Düzenlenen Ya Da Kullanılan Faturalarda Kaç Defa Hapis Cezast Istenebilir?, http://www.muhasebetr.com/yazarlarimiz/ekremisik/001/ Erişim Tarihi: 02.12 .2016

İÇEL, K. (2007), "Ceza Hukukunda Temel Kusurluluk Şekli Kast”, İstanbul Ticaret Üniversitesi Sosyal Bilimler Dergisi, S: 12, 61-70.

KARAKOÇ, Y. (2011), Vergi Hukuku (5. Bası), Ankara: Yetkin Yayınları.

KARAKOÇ, Y. (2016), Vergi Ceza Hukuku, Ankara: Yetkin Yayınları.

MALKOÇ, İ. (2013), Açıklamalı Türk Ceza Kanunu, 1. Cilt, Ankara: Sözkesen Matbaacılık. 
ÖNCEL, M., KUMRULU, A., ÇAĞAN, N. (2013), Vergi Hukuku (22. Basl). Ankara: Turhan Kitabevi.

ÖZBEK, V. Ö., KANBUR, M. N., BACAKSIZ, P., DOĞAN, K., TEPE, İ., (2010), Türk Ceza Hukuku Genel Hükümler, Ankara: Seçkin.

ÖZGENÇ, İ. (2009), Türk Ceza Hukuku Genel Hükümler, Ankara: Seçkin.

ÖZYER, M. A. (2015), Açılama ve Örneklerle Vergi Usul Kanunu Uygulaması, İstanbul: Maliye Hesap Uzmanları Derneği.

PARLAR, A., DEMIREL, G.,(2002), Açılklamalı-İçtihatlı Adli-İdari Vergi Suçları, Ankara: Adil Yayınevi.

SABAN, N. (2006), Vergi Hukuku, İstanbul: Beta.

ŞENYÜZ, D. (2015), Vergi Ceza Hukuku, Bursa: Ekin.

TAŞTAN, M. (2014), "Vergi Kaçakçılığı Suçlarından Muhteviyatı İtibariyle Yanıltıcı Belge Düzenleme ve Kullanma Suçu”, Adalet Dergisi, S: 48, 208-233.

TOROSLU, N. (2009), Ceza Hukuku Genel Kısım, Ankara: Savaş Yayınevi.

UĞUR, H., ELİBOL, M. (2015), Açıklamalı-İçtihatlı Vergi Suçları, Ankara: Adalet Yayınevi.

ÜREL, G. (2015), Güncel Vergi Usul Kanunu Uygulaması, Ankara: Seçkin. 